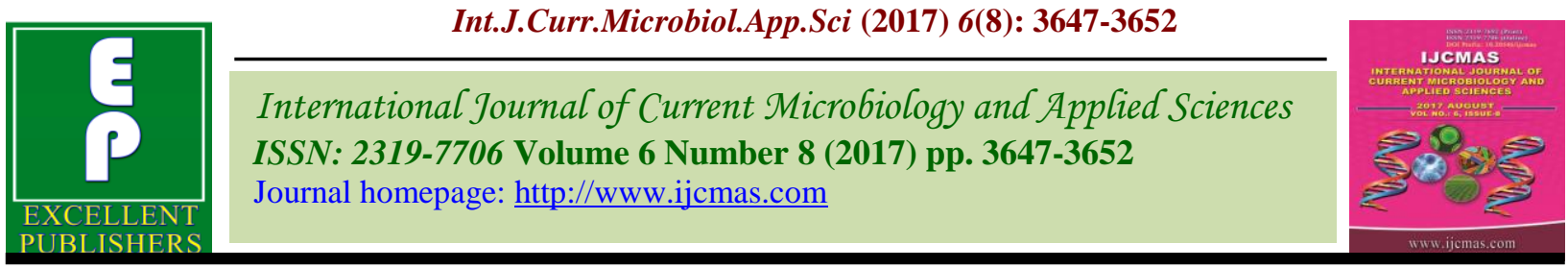

Original Research Article

https://doi.org/10.20546/ijcmas.2017.608.441

\title{
Management of Dry Root Rot Caused by Rhizoctonia solani in Organic Gram
}

\author{
Amit Trivedi*, S.K. Sharma, Roshan Chaudhary, D.K. Jajoria, \\ Ravindra Kumar Jain and Sharvan Kumar Yadav
}

\author{
Organic Farming Unit, Directorate of Research, MPUAT, Udaipur 313001 Rajasthan, India \\ *Corresponding author
}

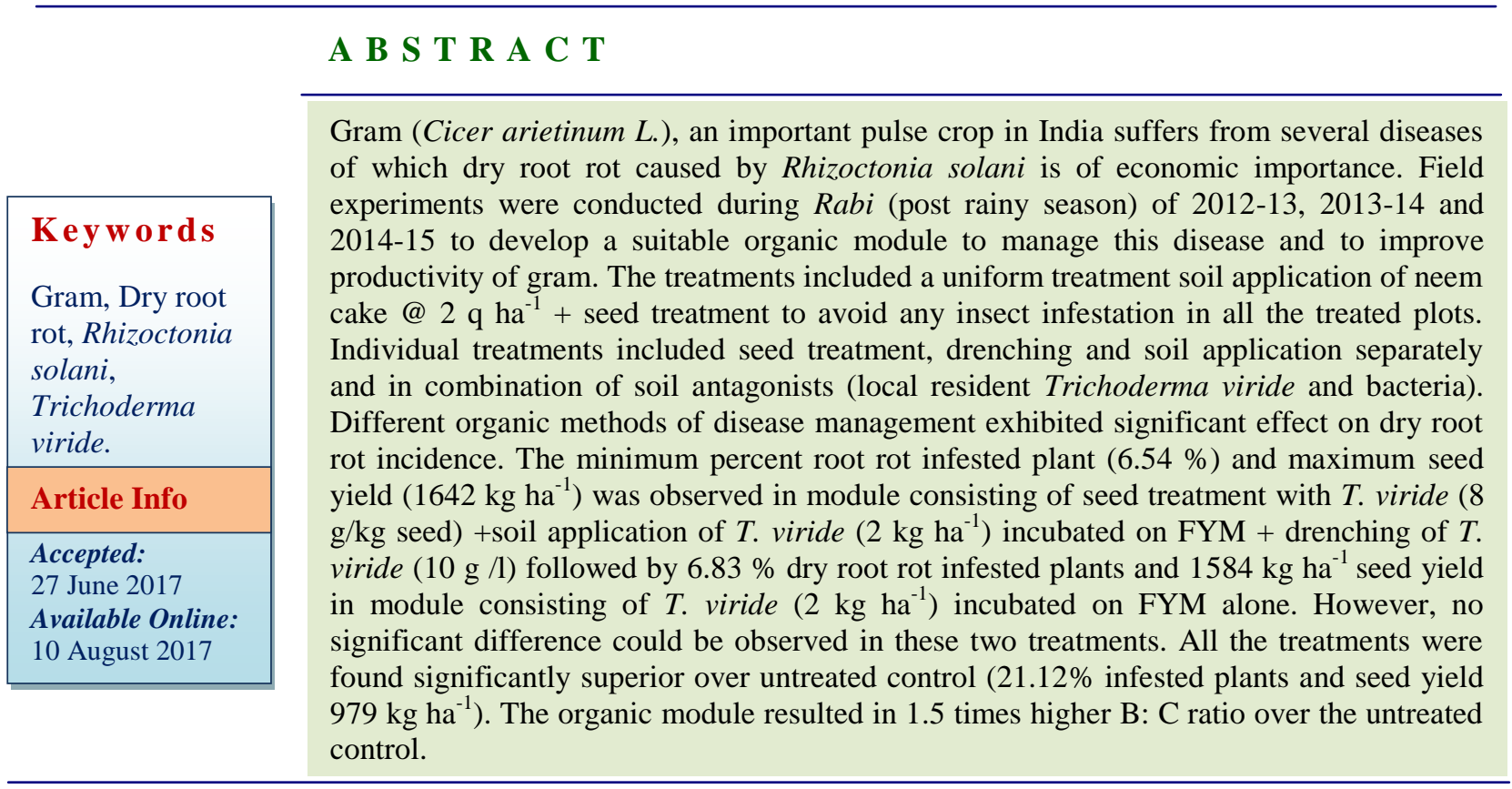

\section{Introduction}

Organic farming is being practiced in 170 countries of the world. With increasing awareness of the consumers towards quality products free from chemical residues, pesticide and the environmental protection area under organic farming in India is increasing. India's rank in terms of World's Organic Agricultural land was 15 as per 2013 data (FIBL, 2015). The total area under organic certification is 5.71 million ha (FIBL, 2015). This includes $26 \%$ cultivable area with 1.49 million ha and rest $74 \%$ (4.22 million hectare) forest and wild area for collection of minor forest produces. India produced around 1.35 million MT of certified organic products. In Rajasthan, Cultivated area under organic farming has grown to 66020.35 ha. (APEDA, 2015). In India, Organic pulse production in Rajasthan represent a very negligible part of our total pulse production.

One of the constraints in increasing the area under organic pulse production is the lack of suitable organic production practices for different agro-climatic regions. Gram (Cicer arietinum $\mathrm{L}$.) is grown in stress environments with low cost input and green pods are used as vegetable. 
Gram is attacked by a large number of diverse plant pathogens, causing different types of diseases. About 172 pathogens including fungi, bacteria, viruses and nematodes have been reported to infect the crop, out of which 89 have been reported from India alone. In last few decades there have been some shifts in disease scenario in gram, and dry root-rot has become wide spread and economically injurious. Root rot caused by Rhizoctonia solani is one of the most devastating and challenging disease problems, which can damage the crop at any stage. A loss of 10 $15 \%$ due to dry root rot in the yield has been reported. Popular resistant varieties against the disease are not available. The present study was undertaken to standardize an ecofriendly disease management module for an organic farming system of gram.

\section{Materials and Methods}

\section{Field experiment}

Experiment was conducted at Instructional Farm, Rajasthan College of Agriculture, MPUAT, Udaipur in three consecutive rabi season of 2012-13, 2013-14 and 2014-15 in a fixed plot. The region has a semi-arid climate. The soil of the experimental fields is sandyloam in texture, slightly alkaline ( $\mathrm{pH} 7.9)$, having low organic carbon (0.42) and available nitrogen $\left(223.42 \mathrm{~kg} \mathrm{ha}^{-1}\right)$, medium available phosphorus (13.52 $\left.\mathrm{kg} \mathrm{ha}^{-1}\right)$ and high available potassium $\left(218.54 \mathrm{~kg} \mathrm{ha}^{-1}\right)$. No inorganic fertilizer was applied to the crop during the three years. The gram variety 'GNG-469' was sown. The common treatment soil application of neem cake at $2 \mathrm{q}$ $\mathrm{ha}^{-1}$ (for soil borne insects) was applied in all plots except control. For management of dry root rot, individual treatments included seed treatment, drenching and soil application separately and in combination of soil antagonists (local resident Trichoderma viride and bacteria). Treatments were Seed treatment with $T$. viride $\left(8 \mathrm{~g} \mathrm{~kg}^{-1}\right.$ seed), Seed treatment with Bacterial Antagonist $\left(8 \mathrm{~g} \mathrm{~kg}^{-1}\right.$ seed), Seed treatment with $T$. viride + Seed treatment with Bacterial Antagonist $\left(8 \mathrm{~g} \mathrm{~kg}^{-1}\right.$ seed), Seed treatment with neem oil $\left(2 \mathrm{ml} \mathrm{kg}^{-1}\right.$ seed), Soil application of T. viride $\left(2 \mathrm{~kg} \mathrm{ha}^{-1}\right)$ incubated on FYM, drenching of $T$. viride $(10$ $\left.\mathrm{g} \mathrm{l}^{-1}\right)$, Seed treatment with $T$. viride $\left(8 \mathrm{~g} \mathrm{~kg}^{-1}\right.$ seed) + Soil application of $T$. viride $\left(2 \mathrm{~kg} \mathrm{ha}^{-1}\right)$ incubated on FYM + Drenching of $T$. viride $\left(10 \mathrm{~g} \mathrm{l}^{-1}\right)$ was used. Thus, there were seven treatments and a control. In total there were eight treatments with three replications. The experiment was carried out in $5 \mathrm{~m} \times 4.5 \mathrm{~m}$ plots in a Randomized Block Design. Each plot had 20 rows of $4.5 \mathrm{~m}$ length with 45 plants in each row.

\section{Data recording and analysis}

Observations for dry root rot were recorded by counting the total number of plants per plot and number of infected plants, and percentage infected plants were calculated. Final observations for dry root rot were recorded 100 days after the sowing. All the data were subjected to analysis of variance (ANOVA) and significance of treatment means was followed by comparing the LSD at $5 \%$ level of probability.

\section{Economic evaluation}

The gross returns, cost of cultivation, net returns and benefit: cost ratio (B: $\mathrm{C}$ ratio) were calculated by using prevailing prices of inputs and outputs. The neem cake costed Rs $10 \mathrm{~kg}^{-1}$ (total Rs $2000 \mathrm{ha}^{-1}$ ), FYM costed Rs 6 $\mathrm{kg}^{-1}$ (total Rs $6000 \mathrm{ha}^{-1}$, T. viride formulation Rs $110 \mathrm{~kg}^{-1}$ (total Rs $440 \mathrm{ha}^{-1}$ ) and Bacterial antagonist costed Rs.200 $\mathrm{Kg}^{-1}$ (total Rs 200 ha-1), The cost of seed for variety GNG-469 was Rs $50 \mathrm{~kg}^{-1}$, (total Rs $4000 \mathrm{ha}^{-1}$ ), Total labour charges including land preparation, sowing, furrow opening, treatment application, intercultural operations, irrigations, harvesting and threshing cost Rs. 
12610 ha $^{-1}$ (per unit cost @ Rs 130 mandays). The selling price of gram seed (in the local agricultural market yard in Udaipur) was Rs. $45 \mathrm{~kg}^{-1}, 50 \mathrm{~kg}^{-1}$ and $55 \mathrm{~kg}^{-1}$ in year 2012-13, 2013-14 and 2014-15 respectively.

\section{Results and Discussion}

\section{Effect on disease incidence}

The pooled data of three years i.e. 2012-13, 2013-14 and 2014-15 revealed a significant effect of organic methods of disease management on dry root rot incidence. The disease was more pronounced at 100 DAS. The minimum percent root rot infested plants $(6.54 \%)$ was observed in plots with seed treatment with $T$. viride $\left(8 \mathrm{~g} \mathrm{~kg}^{-1}\right.$ seed $)+$ soil application of $T$. viride $\left(2 \mathrm{~kg} \mathrm{ha}^{-1}\right)$ incubated on FYM + drenching of $T$. viride $\left(20 \mathrm{~g} \mathrm{l}^{-1}\right)$ followed by $6.83 \%$ in soil application of $T$. viride $\left(2 \mathrm{~kg} \mathrm{ha}^{-1}\right)$ incubated on FYM. However, no significant difference could be observed in these two treatments. Next best treatment was Drenching of T. viride $\left(10 \mathrm{~g} \mathrm{l}^{-1}\right)$ with $9.20 \%$ infested plants. The treatments with seed treatments of $T$. viride + Bacterial Antagonist ( $8 \mathrm{~g} \mathrm{~kg}^{-1}$ seed), T. viride $\left(8 \mathrm{~g} \mathrm{~kg}^{-1}\right.$ seed) alone and Bacterial Antagonist $\left(8 \mathrm{~g} \mathrm{~kg}^{-1}\right.$ seed) alone showed $11.33 \%, 12.29 \%$ and $12.34 \%$ root rot infested plants respectively and effect of three of these treatments was found at par. Maximum percent root rot (18.21\%) among all treatments was observed in plots with seed treatment of neem oil @ 2 $\mathrm{ml} \mathrm{L}^{-1}$. All the treatments were found significantly superior over untreated control where maximum percent root rot $(21.12 \%)$ was observed.

\section{Effect on seed yield and number of pods per plant}

The pooled data of three years i.e. 2012-13, 2013-14 and 2014-15 indicated a significant effect of organic methods of disease management on seed yield and plant attributes in gram. The maximum seed yield (1642 Kg $\left.\mathrm{ha}^{-1}\right)$ was observed in plots with seed treatment with $T$. viride $\left(8 \mathrm{~g} \mathrm{~kg}^{-1}\right.$ seed $)+$ soil application of $T$. viride $\left(2 \mathrm{Kg} \mathrm{ha}^{-1}\right)$ incubated on FYM + drenching of $T$. viride $(10 \mathrm{~g} / \mathrm{l})$ followed by $1584 \mathrm{Kg} \mathrm{ha}^{-1}$ in soil application of $T$. viride $\left(2 \mathrm{Kg} \mathrm{ha}^{-1}\right)$ incubate on FYM.

However, no significant difference could be observed in these two treatments. Next best treatment was drenching of T. viride $\left(20 \mathrm{~g} \mathrm{l}^{-1}\right)$ with seed yield $\left(1428 \mathrm{Kg} \mathrm{ha}^{-1}\right)$. The treatments with seed treatments of $T$. viride + Bacterial Antagonist ( $8 \mathrm{~g} \mathrm{~kg}^{-1}$ seed), Bacterial Antagonist ( $8 \mathrm{~g} \mathrm{~kg}^{-1}$ seed) alone and $T$. viride $\left(8 \mathrm{~g} \mathrm{~kg}^{-1}\right.$ seed) alone showed 1207, 1170 and $1100 \mathrm{Kg} \mathrm{ha}^{-1}$ seed yield respectively and effect of three of these treatments was found at par. Minimum seed yield (1053 $\left.\mathrm{Kg} \mathrm{ha}^{-1}\right)$ among all treatments was observed in plots with seed treatment of neem oil @ 2 ml/L. All the treatments were found significantly superior over untreated control where minimum seed yield (979 $\left.\mathrm{Kg} \mathrm{ha}^{-1}\right)$ was observed.

\section{Benefits of disease management module}

Maximum net returns of Rs $40091 \mathrm{ha}^{-1}$ was obtained with seed treatment with $T$. viride $(8$ $\mathrm{g} \mathrm{kg}^{-1}$ seed) + soil application of $T$. viride $(2$ $\mathrm{kg} \mathrm{ha}^{-1}$ ) incubated on FYM + drenching of $T$. viride $\left(10 \mathrm{~g} \mathrm{l}^{-1}\right)$ which recorded an increase of Rs $25316 \mathrm{ha}^{-1}$, Rs $21411 \mathrm{ha}^{-1}$, $19486 \mathrm{ha}^{-1}$, $16357 \mathrm{ha}^{-1}, 14905 \mathrm{ha}^{-1}, 6972 \mathrm{ha}^{-1}$, and $903 \mathrm{ha}^{-1}$ over seed treatment with neem oil $\left(2 \mathrm{ml} \mathrm{kg}^{-1}\right.$ seed), seed treatment with $T$. viride $\left(8 \mathrm{~g} \mathrm{~kg}^{-1}\right.$ seed), seed treatment with Bacterial Antagonist (8 $\mathrm{g} \mathrm{kg}^{-1}$ seed), seed treatment with $T$. viride + seed treatment with Bacterial Antagonist ( $8 \mathrm{~g} \mathrm{~kg}^{-1}$ seed), Drenching of $T$. viride $\left(10 \mathrm{~g} \mathrm{l}^{-1}\right)$, soil application of $T$. viride $(2$ $\mathrm{kg} \mathrm{ha}{ }^{-1}$ ) incubated on FYM and control, respectively. This indicates that by application of organic practices for control of 
dry root rot gram, an additional returns of Rs $25316 \mathrm{ha}^{-1}$ can be obtained. Similarly maximum B:C ratio 2.39 was obtained with soil application of $T$. viride $\left(2 \mathrm{~kg} \mathrm{ha}^{-1}\right)$ incubated on FYM which recorded an increase in $\mathrm{B}: \mathrm{C}$ ratio of $0.04,0.17,0.42,0.46$, $0.54,0.69$ and 0.82 over seed treatment with T. viride $\left(8 \mathrm{~g} \mathrm{~kg}^{-1}\right.$ seed $)+$ soil application of $T$. viride $\left(2 \mathrm{~kg} \mathrm{ha}^{-1}\right)$ incubated on FYM + drenching of T. viride $\left(20 \mathrm{~g} \mathrm{l}^{-1}\right)$, drenching of T. viride $\left(10 \mathrm{~g} \mathrm{l}^{-1}\right)$, soil application with $T$. viride + soil application with Bactereial Antagonist ( $8 \mathrm{~g} \mathrm{~kg}^{-1}$ seed), soil application with Bacterial Antagonist $\left(8 \mathrm{~g} \mathrm{~kg}^{-1}\right.$ seed), soil application with $T$. viride $\left(8 \mathrm{~g} \mathrm{~kg}^{-1}\right.$ seed) soil application with neem oil $(2 \mathrm{ml} / \mathrm{kg}$ seed $)$ and control, respectively. This indicate that by application of organic practices for control of dry root rot in gram, an additional increase in $\mathrm{B}: \mathrm{C}$ ratio of 0.82 can be obtained.

The highest net returns (Rs. 40091/- $\mathrm{ha}^{-1}$ ) and B: C ratio 2.39 was observed in seed treatment with $T$. viride $\left(8 \mathrm{~g} \mathrm{~kg}^{-1}\right.$ seed $)+$ soil application of $T$. viride $\left(2 \mathrm{~kg} \mathrm{ha}^{-1}\right)$ incubated on FYM + drenching of $T$. viride $\left(20 \mathrm{~g} \mathrm{l}^{-1}\right)$, soil application of $T$. viride $\left(2 \mathrm{~kg} \mathrm{ha}^{-1}\right)$ with FYM which were significantly higher than control Rs.25366/- ha ${ }^{-1}$ and 0.82 (Table 3).

Table.1 Effect of organic treatments on disease in gram Pooled data

(Rabi 2012-13, 2013-14 and 2014-15)

\begin{tabular}{|c|c|c|}
\hline Treatments* & Root $\operatorname{rot}(\%)$ & Yield $\left(q\right.$ ha $\left.^{-1}\right)$ \\
\hline Seed Treatment with $T$. viride $\left(8 \mathrm{~g} \mathrm{~kg}^{-1}\right.$ seed $)$ & $12.29(20.22)$ & 1100 \\
\hline Seed Treatment with Bacterial Antagonist $\left(8 \mathrm{~g} \mathrm{~kg}^{-1}\right.$ seed $)$ & $12.34(20.42)$ & 1170 \\
\hline $\begin{array}{l}\text { Seed Treatment with Tricho }\left(8 \mathrm{~g} \mathrm{~kg}^{-1} \text { seed }\right)+\text { Seed Treatment } \\
\text { with Bacterial Antagonist }\left(8 \mathrm{~g} \mathrm{~kg}^{-1} \text { seed }\right)\end{array}$ & $11.33(19.37)$ & 1207 \\
\hline Seed Treatment with neem oil $\left(2 \mathrm{ml} \mathrm{kg}^{-1}\right.$ seed $)$ & $18.21(25.18)$ & 1053 \\
\hline Soil Application T. viride $\left(2 \mathrm{~kg} \mathrm{ha}^{-1}\right)$ incubated on FYM & $6.83(15.10)$ & 1584 \\
\hline Drenching of T. viride $\left(10 \mathrm{~g} \mathrm{l}^{-1}\right)$ & $9.20(17.62)$ & 1428 \\
\hline $\begin{array}{l}\text { Seed Treatment } T \text {. viride }\left(8 \mathrm{~g} \mathrm{~kg}^{-1} \text { seed }\right)+\text { Soil Application } T \text {. } \\
\text { viride }\left(2 \mathrm{~kg} \mathrm{ha}^{-1}\right) \text { incubated on FYM + Drenching of } T \text {. viride } \\
\left(10 \mathrm{~g} \mathrm{l}^{-1}\right)\end{array}$ & $6.54(14.56)$ & 1642 \\
\hline Control & $21.12(27.32)$ & 979 \\
\hline CD at $5 \%$ & $0.66(0.63)$ & 106 \\
\hline
\end{tabular}

* Soil application of neem cake at $2 \mathrm{q} / \mathrm{ha}$ (for soil borne insects) in all the treatment plots except untreated control. 
Table.2 Control of dry root rot of gram under organic farming (Economics)

\begin{tabular}{|c|c|c|c|c|c|c|c|c|}
\hline \multirow{2}{*}{ Treatments } & \multicolumn{4}{|c|}{ Net returns (Rs/ha) } & \multicolumn{4}{|c|}{$\mathrm{B}: \mathrm{C}$ ratio } \\
\hline & 2012-13 & 2013-14 & 2014-15 & Pooled & 2012-13 & 2013-14 & 2014-15 & Pooled \\
\hline Seed Treatment with $T$. viride $\left(8 \mathrm{~g} \mathrm{~kg}^{-1}\right.$ seed $)$ & 28061 & 22350 & 11403 & 20605 & 2.13 & 1.88 & 1.31 & 1.77 \\
\hline Seed Treatment with Bacterial Antagonist ( $8 \mathrm{~g} \mathrm{~kg}^{-1}$ seed $)$ & 31317 & 25876 & 14008 & 23734 & 2.26 & 2.02 & 1.38 & 1.89 \\
\hline $\begin{array}{l}\text { Seed Treatment with Tricho }\left(8 \mathrm{~g} \mathrm{~kg}^{-1} \text { seed }\right)+\text { Seed } \\
\text { Treatment with Bacterial Antagonist }\left(8 \mathrm{~g} \mathrm{~kg}^{-1} \text { seed }\right)\end{array}$ & 32754 & 27257 & 15548 & 25186 & 2.32 & 2.07 & 1.42 & 1.93 \\
\hline Seed Treatment with neem oil $\left(2 \mathrm{ml} \mathrm{kg}^{-1}\right.$ seed $)$ & 25907 & 20196 & 9938 & 18680 & 2.05 & 1.79 & 1.27 & 1.70 \\
\hline Soil Application T. viride $\left(2 \mathrm{~kg} \mathrm{ha}^{-1}\right)$ incubated on FYM & 46744 & 41155 & 29666 & 39188 & 2.82 & 2.56 & 1.79 & 2.39 \\
\hline Drenching of $T$. viride $\left(10 \mathrm{~g} \mathrm{l}^{-1}\right)$ & 41096 & 35113 & 23147 & 33119 & 2.59 & 2.32 & 1.61 & 2.18 \\
\hline $\begin{array}{l}\text { Seed Treatment } T \text {. viride }\left(8 \mathrm{~g} \mathrm{~kg}^{-1} \text { seed }\right)+\text { Soil Application } \\
T \text {. viride }\left(2 \mathrm{~kg} \mathrm{ha}^{-1}\right) \text { incubated on FYM + Drenching of } T \text {. } \\
\text { viride }\left(10 \mathrm{~g} \mathrm{l}^{-1}\right)\end{array}$ & 47454 & 42367 & 30452 & 40091 & 2.75 & 2.53 & 1.78 & 2.35 \\
\hline Control & 23517 & 16286 & 4374 & 14725 & 1.95 & 1.64 & 1.12 & 1.57 \\
\hline $\mathrm{CD}$ at $5 \%$ & 4898 & 6592 & 7260 & 4170 & 0.19 & 0.25 & 0.19 & 0.14 \\
\hline
\end{tabular}

** Soil application of neem cake at $2 \mathrm{q} / \mathrm{ha}$ (for soil borne insects) in all the treatments excepting untreated control

*The selling price of gram seed (in the local agricultural market yard in Udaipur) was Rs. $45 \mathrm{~kg}^{-1}, 50 \mathrm{~kg}^{-1}$ and $55 \mathrm{~kg}^{-1}$ in year 2012-13, 2013-14 and 2014-15 respectively. The calculations are based for seed yield only. 
The highest net returns (Rs. 40091/- ha ${ }^{-1}$ ) and B: $\mathrm{C}$ ratio 2.39 was observed in Seed Treatment with $T$. viride $\left(8 \mathrm{~g} \mathrm{~kg}^{-1}\right.$ seed $)+$ Soil Application of $T$. viride $\left(2 \mathrm{~kg} \mathrm{ha}^{-1}\right)$ incubated on FYM + Drenching of $T$. viride $\left(20 \mathrm{~g} \mathrm{l}^{-1}\right)$, Soil Application of $T$. viride $\left(2 \mathrm{~kg} \mathrm{ha}^{-1}\right)$ with FYM which were significantly higher than control Rs.25366/- ha ${ }^{-1}$ and 0.82 (Table 3).

Past research indicated that Trichoderma can parasitize fungal pathogens and produce antibiotics. Weindling (1932) described in detail the mycoparasitism of a fungal pathogen causing damping off disease ( $R$. solani) by the hyphae of Trichoderma. He also described an antibiotic which was toxic to both $R$. solani and Sclerotinia americana, and named it gliotoxin. Plants treated with Trichoderma in the root zone can produce higher levels of peroxidase, chitinase activity, deposition of callose-enriched wall appositions on the inner surface of cell walls and pathogenesis-related proteins (Howell 2003).

Mechanism used by Trichoderma spp. for control of plant pathogen includes competition, mycoparasitism, antibiosis and induced resistance of the plant host (Chet 2012; Schirmbock et al., 1994). Moreover, Harman et al., 2012 reported that $T$. viride could colonize a root of plants and promote plant growth. These mechanisms are useful for $T$. viride to control pathogens.

Thus, the module involving soil application of neem cake@2 $\mathrm{q} \mathrm{ha}^{-1}+$ seed treatment with $T$. viride $\left(8 \mathrm{~g} \mathrm{~kg}^{-1}\right.$ seed $)+$ soil application of $T$. viride $\left(2 \mathrm{~kg} \mathrm{ha}^{-1}\right)$ incubated on FYM + drenching of $T$. viride $(10 \mathrm{~g} / \mathrm{l})$ proved to be highly effective and economical for successful management of dry root rot disease of gram in an organic farming system in southern Rajasthan conditions. This module can be tested in organic farming systems of other crops as well.

\section{References}

APEDA (Agricultural and Processed Food Products Export Development Authority, Ministry of Commerce and Industry, GoI). 2010-11. www.Apeda.gov.in/www.organicworld.net/fileadmin/document/yearbook/20 12/fibl-ifoam-2012-summary.pdf 2012. sp. - Environmentally friendly.

Chet, I., 2012. Trichoderma sp. Environmentally friendly bio-control agent and inducer of plant resistance to diseases. Proceedings $3^{\text {rd }}$ Global Conference ISMPP "Plant Pathology for food security". pp 224.

Harman. G., Mastouri, F. and Xue, M. 2012. Trichderma - Not just for bio-control anymore. Proceedings $3^{\text {rd }}$ Global Conference ISMPP "Plant Pathology for food security". pp224.

Howell, C.R., 2003. Mechanisms Employed by Trichoderma Species in the Biological Control of Plant Diseases: The History and Evolution of Current Concepts. Plant Dis, 87: 4-10.

Pimentel, D., Zuniga, R. and Morrison, D. 2005. Update on the environmental and economic costs associated with alien-invasive species in the United States. Ecol. Econ., 52: 273 288.

Schirmbock, M., Lorito, M., Wang, Y.L., Hayes, C.K., Arisan-Atac, I., Scala, F., Harman, G.E. and Kubicek, C.P. 1994. Parallel formation and synergism of hydrolytic enzymes and peptaibol antibiotics, molecular mechanisms involved in the antagonistic action of Trichoderma harzianum against phytopathogenic fungi. Appl. Environ. Microbiol, 60: 4364-4370.

Weindling, R., 1932. Trichoderma lignorum as a parasite of other soil fungi. Phytopathology, 22: 837- 845 .

\section{How to cite this article:}

Amit Trivedi, S.K. Sharma, Roshan Chaudhary, D.K. Jajoria, Ravindra Kumar Jain and Sharvan Kumar Yadav. 2017. Management of Dry Root Rot Caused by Rhizoctonia solani in Organic Gram. Int.J.Curr.Microbiol.App.Sci. 6(8): 3647-3652.

doi: https://doi.org/10.20546/ijcmas.2017.608.441 